\title{
Job Motivation in an Organization: The Relationship with Transactional Leadership Style in Driving Employees' Job Satisfaction
}

\author{
Abdullah Abdullah ${ }^{1 *}$, Dinda Azzahra ${ }^{1}$ \\ ${ }^{1}$ Faculty of Economics and Business, Universitas Prof. Dr. Moestopo (Beragama), Jakarta - 10270, Indonesia \\ ${ }^{*}$ Corresponding Author. Email: bankdoell@yahoo.com
}

\begin{abstract}
Job satisfaction may be determined by the effects of transactional leadership style and employees' motivation. The study aimed to reveal the variables that are related to employees' job satisfaction at PT. ABM Investama, in South Jakarta, Indonesia. This research used an explanatory method, associative, and quantitative-qualitative analysis with a survey approach. The result of this study is that there is a significant effect of Transactional Leadership Style $\left(\mathrm{X}_{1}\right)$ on Employees' Job Satisfaction (Y), in which this result shows that Employees' Job Satisfaction $(\mathrm{Y})$ can be formulated in a simple-linear regression equation: $\mathrm{Y}=32.643+0.978 \mathrm{X}_{1}$. There is also a significant effect of Job Motivation $\left(\mathrm{X}_{2}\right)$ on Employee's Job Satisfaction (Y), in which this result shows that Employee's Job Satisfaction $(\mathrm{Y})$ can be formulated in a simple-linear regression equation: $\mathrm{Y}=44.416+0.428$ $\mathrm{X}_{2}$. In addition, there is a significant effect of the variables of Transactional Leadership Style $\left(\mathrm{X}_{1}\right)$ and Job Motivation $\left(\mathrm{X}_{2}\right)$ on Employee's Job Satisfaction $(\mathrm{Y})$ simultaneously, in which the Employees' Job Satisfaction $(\mathrm{Y})$ can be formulated in a multiple-linear regression equation: $\mathrm{Y}=21.925+0.814 \mathrm{X}_{1}+0.266 \mathrm{X}_{2}$.
\end{abstract}

Keywords: Transactional leadership style, motivation, employee's job satisfaction

\section{INTRODUCTION}

Job satisfaction is an assessment of the work being done, both as pleasant or unpleasant. It is one of the important factors in producing optimal results. Employees who are satisfied with their jobs will show the behaviors in accordance with the work they do as a result of the influence of themselves or from the outside of their environment.

The leader's behavior or style is another important factor that can affect employee's job satisfaction. The leader directs the goals, plans, organizes, moves, and controls all the resources so that the company's goals can be achieved. Transactional leadership is a kind of leadership style that can provide punishment or rewards for employees in carrying out their tasks and orders.

Motivation is an internal condition that can arouse the employees to act, who are motivated and interested in doing certain activities. Motivation has an important role in employees' job satisfaction. Leaders need to motivate their employees to be willing to work sincerely in order to achieve predetermined goals.

During a pre-survey activity with the Human Resource Manager of PT. ABM Investama Tbk, it was said that job indicators in the company such as promotions and salaries resulted in dissatisfaction.

As a service provider, PT. ABM Investama is required to provide quality services so that it is not less competitive with other service-provider companies. Quality services are created if the company has leaders who are able to guide and pay attention to the interests of employees, have high work motivation, and can satisfy the employees with what they do. The researchers tried to examine the extent to which the variables of leadership style and job motivation can affect job satisfaction among the employees of PT. ABM Investama. Thus, the problems formulation based on the background, problem identification, and problem boundaries are as follows: 1) Does the transactional leadership style affect job satisfaction of PT. ABM Investama employees? 2) Does work motivation affect job satisfaction of PT. ABM Investama employees? 3) Is there a significant effect of transactional leadership style and job motivation simultaneously on job satisfaction of PT. ABM Investama employees?

\section{RELATED WORK}

According to the types of variable being observed, we divided the variables into three categories.

\subsection{Job Satisfaction}

[1] defined job satisfaction as a positive feeling about work as a result of an evaluation of its characteristics. This feeling can also be interpreted as a feeling that supports or does not support an employee who is related to his / her job or condition as quoted from [2]. This definition shows that job satisfaction is not a single concept. Rather, a person can be relatively satisfied with one aspect of his / her job and dissatisfied with one or more other aspects. 
A popular job-satisfaction measurement tool is the Job Descriptive Index (JDI) compiled by [3], which consists of five indicators, namely: the work itself, supervision, relationship with co-workers, promotion, and salary / wages.

\subsection{Transactional Leadership Style}

Transactional leadership, according to [4], is the leadership that assists an organization to reach its goals efficiently. These goals can be achieved through linking the job performance to reward assessments and ensuring that workers have the resources needed to complete their works. According to Bycio and Koh in [5], transactional leadership is a kind of leadership style in which a leader focuses his / her attention on interpersonal transactions between leaders and employees that involve the exchanged relationships. This exchange is based on an agreement regarding the classification of objectives, work standards, work assignments, and rewards.

In addition to that, Bass in [4] stated that the characteristics of a transactional leadership style are contingent rewards, management-by-exception (active), management-byexception (passive), and laissez-faire.

\subsection{Job Motivation}

According to Weiner, as quoted by [6], motivation was defined as an internal condition that arouses us to act, encourages us to achieve certain goals, and keeps us interested in certain activities. Meanwhile, [7] stated that motivation is formed from the attitude of employees in dealing with work situations in the company. Therefore, motivation is a condition or energy that moves employees who are directed or aimed at achieving company's organizational goals.

The most common motivation theory is the theory of Abraham Maslow's hierarchy of needs, which consists of five hierarchies of needs, namely: physiological needs, security needs, social needs, reward needs, and selfactualization needs.

\subsection{Research Framework}

The framework of this research can be seen in Figure 1 as follow:

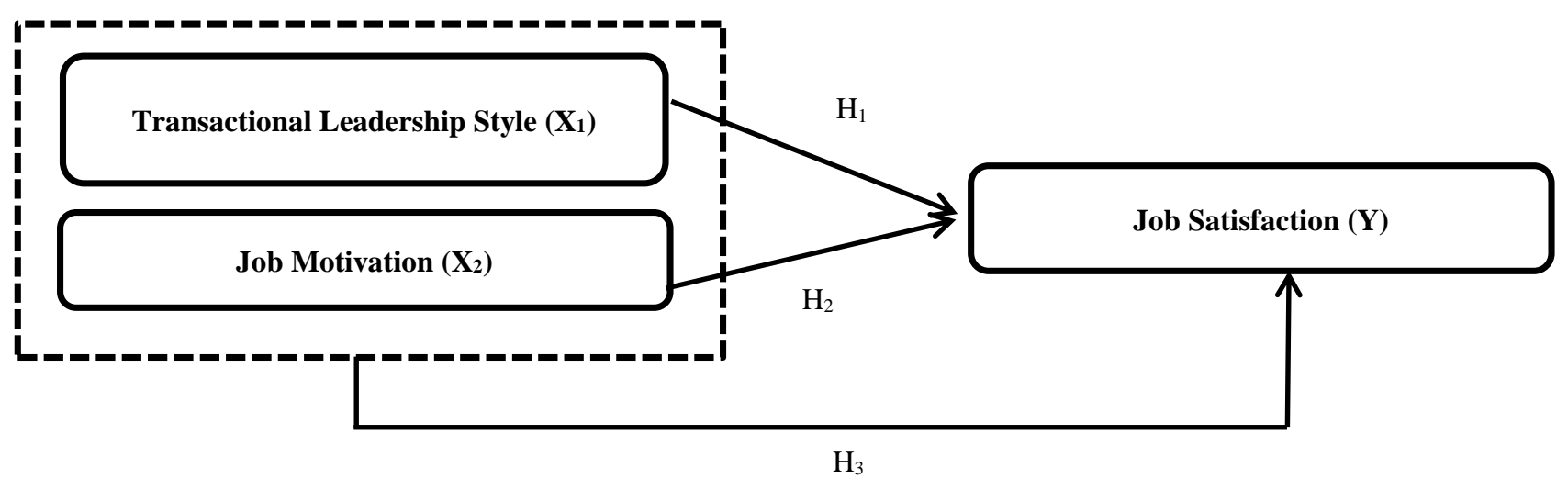

Figure 1 Research Framework

\section{RESEARCH METHODOLOGY}

The method used in this research is the descriptive method with quantitative approach. The population in this study was all employees of PT. ABM Investama Jakarta, Indonesia amounting to 46 full-time employees. [8] suggested that if the subjects studied are less than 100, it would be better if all of them are taken so that the research becomes a population study. Then all members of the population were taken as samples in this study with a total of 46 employees. The sampling technique used was the non-probability sampling, namely the saturated sampling, because it took $100 \%$ of the population as a sample due to the relatively small amount population.

The data collection technique used was in form of a closedended type of questionnaire, which is a list of questions whereas the alternative answers have been provided so that the respondents just have to choose the right answer. This questionnaire was created using a five-point Likert-scale. In a Likert-scale, each question contains five alternative answers with gradations from positive to negative. In the questionnaire distributed to respondents, each question contains 5 (five)-answer choices, each of which is given a score ranging from 1 to 5 . The highest choice is given a value of 5 and the lowest choice is given a value of 1 .

\section{RESEARCH RESULTS}

\subsection{Normality and Homogeneity Tests}

In data normality assessment using the KolmogorovSmirnov test, data is declared normally-distributed if the Sig. value is greater than Alpha. Based on Table 1, the data used in this research is normality-distributed. 
Table 1 The Result of Normality Test

\begin{tabular}{|l|c|c|c|c|}
\hline \multirow{2}{*}{ Variable } & \multicolumn{3}{|c|}{ Kolmogorov-Smirnov Test } \\
\cline { 2 - 5 } & Sig. Value & $\langle/\rangle$ & Alpha & Remarks \\
\hline Job Satisfaction (Y) & 0.200 & $>$ & 0.05 & Normal \\
\hline Transactional Leadership Style $\left(\mathrm{X}_{1}\right)$ & 0.200 & $>$ & 0.05 & Normal \\
\hline Job Motivation $\left(\mathrm{X}_{2}\right)$ & 0.200 & \rangle & 0.05 & Normal \\
\hline
\end{tabular}

Source: Data Analysis Results (2020)

Table 2 shows the homogeneity test result, which was carried out using the Levene Test. Data is declared homogeneous, if the Sig. value is greater than Alpha. Based on Table 2, the data used in this research is homogeneous.

Table 2 The Result of Homogeneity Test

\begin{tabular}{|c|c|c|c|c|}
\hline \multirow{2}{*}{ Variable } & \multicolumn{4}{|c|}{ Levene Test } \\
\cline { 2 - 5 } & Sig. Value & $</>$ & Alpha & Remarks \\
\hline Variable Y on $\mathrm{X}_{1}$ & 0.868 & $>$ & 0.05 & Homogenous \\
\hline Variable Y on $\mathrm{X}_{2}$ & 0.054 & $>$ & 0.05 & Homogenous \\
\hline
\end{tabular}

Source: Data Analysis Results (2020)

\subsection{Hypothesis 1: The Effect of Transactional Leadership Style on Job Satisfaction}

Table 3 pictures the effect of the Transactional Leadership Style $\left(\mathrm{X}_{1}\right)$ on Job Satisfaction $(\mathrm{Y})$, which is shown by the regression equation: $\mathrm{Y}=32.643+0.978 \mathrm{X}_{1}$.

Table 4 shows that F-statistics (49.586) is greater than Ftable (4.06) with a significance level (0.000) less than 0.05 .

Thus, it can be concluded that Transactional Leadership Style $\left(\mathrm{X}_{1}\right)$ has a significant effect on Job Satisfaction (Y).

Table 5 shows that F-statistics $(0.586)$ is less than F-table (2.04) and the significance level $(0.855)$ is greater than 0.05 .
So, it can be concluded that the regression equation of "Y $=$ $32.643+0.978 \mathrm{X}_{1}$ “ is linear.

Table 6 shows the result of simple-correlation test, which produces a number of 0.728 . This indicates that the relationship between Transactional Leadership Style $\left(\mathrm{X}_{1}\right)$ and Employees' Job Satisfaction ( $\mathrm{Y}$ ) is strong. The Coefficient-of-Determination $\left(\mathrm{R}^{2}\right)$ of Transactional Leadership Style $\left(\mathrm{X}_{1}\right)$ towards Job Satisfaction (Y) is 0.530 or $53 \%$. Therefore, this result illustrates that as much as $53 \%$ of variation in Job Satisfaction variable can be explained by the variation in Transactional Leadership Style variable, while the remaining $47 \%$ of variation in Job Satisfaction variable is determined by other variables not examined in this study.

Table 3 Simple-Regression Equation Test: Transactional Leadership Style ( $\left.\mathrm{X}_{1}\right)$ on Job Satisfaction (Y) Coefficients $^{\text {a }}$

\begin{tabular}{|c|c|c|c|c|c|}
\hline \multirow[t]{2}{*}{ Model } & \multicolumn{2}{|c|}{$\begin{array}{l}\text { Unstandardized } \\
\text { Coefficients }\end{array}$} & \multirow{2}{*}{$\begin{array}{c}\begin{array}{c}\text { Standardized } \\
\text { Coefficients }\end{array} \\
\text { Beta } \\
\end{array}$} & \multirow[t]{2}{*}{$\mathrm{t}$} & \multirow[t]{2}{*}{ Sig. } \\
\hline & $\mathrm{B}$ & Std. Error & & & \\
\hline (Constant) & 32.643 & 5.667 & & 5.761 & .000 \\
\hline Transactional Leadership Style $\left(\mathrm{X}_{1}\right)$ & .978 & .139 & .728 & 7.042 & .000 \\
\hline
\end{tabular}

a. Dependent variable: Job Satisfaction (Y)

Source: Data Analysis Results (2020)

Table 4 Significance Test: Transactional Leadership Style Regression $\left(\mathrm{X}_{1}\right)$ on Job Satisfaction (Y)

ANOVA $^{\text {b }}$

\begin{tabular}{|c|l|r|r|r|r|r|}
\hline \multicolumn{2}{|c|}{ Model } & Sum of Squares & df & Mean Square & F & Sig. \\
\hline \multirow{4}{*}{1} & Regression & 566.380 & 1 & 566.380 & 49.586 & $.000^{\mathrm{a}}$ \\
\cline { 2 - 7 } & Residual & 502.577 & 44 & 11.422 & & \\
\cline { 2 - 7 } & Total & 1068.957 & 45 & & & \\
\hline
\end{tabular}

a. Predictors: (Constant), Transactional Leadership Style $\left(\mathrm{X}_{1}\right)$

b. Dependent variable: Job Satisfaction (Y)

Source: Data Analysis Results (2020) 
Table 5 Linearity Test: Transactional Leadership Style Regression $\left(\mathrm{X}_{1}\right)$ on Job Satisfaction (Y) ANOVA Table

\begin{tabular}{|c|c|c|c|c|c|c|}
\hline & & Sum of Squares & $\mathrm{df}$ & $\begin{array}{l}\text { Mean } \\
\text { Square }\end{array}$ & $\mathrm{F}$ & Sig. \\
\hline $\mathrm{Y} *$ & Between (Combined) & 674.273 & 15 & 44.952 & 3.417 & .002 \\
\hline \multirow[t]{4}{*}{$\mathrm{X}_{1}$} & Linearity & 566.380 & 1 & 566.380 & 43.051 & .000 \\
\hline & Deviation from Linearity & 107.893 & 14 & 7.707 & .586 & .855 \\
\hline & Within Groups & 394.683 & 30 & 13.156 & & \\
\hline & Total & 1068.957 & 45 & & & \\
\hline
\end{tabular}

Source: Data Analysis Results (2020)

Table 6 Correlation Test: Transactional Leadership Style $\left(\mathrm{X}_{1}\right)$ and Job Satisfaction (Y)

Measures of Association

\begin{tabular}{|l|c|r|c|r|}
\hline & $\mathrm{R}$ & R-Squared & Eta & Eta Squared \\
\hline $\mathrm{Y} * \mathrm{X}_{1}$ & .728 & .530 & .794 & .631 \\
\hline
\end{tabular}
Source: Data Analysis Results (2020)

\subsection{Hypothesis 2: The Effect of Job Motivation on Job Satisfaction}

The effect of Job Motivation $\left(\mathrm{X}_{2}\right)$ on Job Satisfaction (Y) is shown by the regression equation of: $\mathrm{Y}=44.416+$ $0.428 \mathrm{X}_{2}$, as displayed in Table 7.

Table 8 shows that F-statistics (20.090) is greater than Ftable (4.06) with a significance level (0.000) less than 0.05. Thus, it can be concluded that Job Motivation $\left(\mathrm{X}_{2}\right)$ has a significant effect on Job Satisfaction (Y).

Table 9 shows that F-statistics $(0.555)$ is less than F-table (2.05) and the level of significance $(0.913)$ is greater than
0.05 . So, it can be concluded that the regression equation of "Y $=44.416+0.428 \mathrm{X}_{2}$ " is linear.

Table 10 shows that the result of simple-correlation test produces a number of 0.560 . This indicates that the relationship between Job Motivation $\left(\mathrm{X}_{2}\right)$ and Employees' Job Satisfaction (Y) is moderate. The Coefficient-ofDetermination $\left(\mathrm{R}^{2}\right)$ of Job Motivation $\left(\mathrm{X}_{2}\right)$ towards Job Satisfaction (Y) is 0.313 or $31.3 \%$. Therefore, this result illustrates that as much as $31.3 \%$ of variation in Job Satisfaction variable can be explained by the variation in Job Motivation variable, while the remaining $68.7 \%$ of variation in Job Satisfaction variable is determined by other variables not examined in this study.

Table 7 Simple-Regression Equation Test: Job Motivation $\left(\mathrm{X}_{2}\right)$ on Job Satisfaction (Y) Coefficients $^{\mathbf{a}}$

\begin{tabular}{|c|c|c|c|c|c|}
\hline \multirow[t]{2}{*}{ Model } & \multicolumn{2}{|c|}{$\begin{array}{c}\text { Unstandardized } \\
\text { Coefficients }\end{array}$} & \multirow{2}{*}{$\begin{array}{c}\begin{array}{c}\text { Standardized } \\
\text { Coefficients }\end{array} \\
\text { Beta }\end{array}$} & \multirow[t]{2}{*}{$\mathrm{t}$} & \multirow[t]{2}{*}{ Sig. } \\
\hline & $\mathrm{B}$ & Std. Error & & & \\
\hline $1 \quad$ (Constant) & 44.416 & 6.270 & & 7.084 & .000 \\
\hline Job Motivation $\left(\mathrm{X}_{2}\right)$ & .428 & .096 & .560 & 4.482 & .000 \\
\hline
\end{tabular}

a. Dependent variable: Job Satisfaction (Y)

Source: Data Analysis Results (2020)

Table 8 Significance Test: Job Motivation $\left(\mathrm{X}_{2}\right)$ on Job Satisfaction (Y)

ANOVA $^{\mathrm{b}}$

\begin{tabular}{|ll|r|r|r|c|l|}
\hline \multicolumn{1}{|c|}{ Model } & Sum of Squares & df & Mean Square & F & Sig. \\
\hline 1 & Regression & 335.085 & 1 & 335.085 & 20.090 & $.000^{\mathrm{a}}$ \\
Residual & 733.872 & 44 & 16.679 & & \\
Total & 1068.957 & 45 & & & \\
\hline
\end{tabular}

a. Predictors: (Constant), Job Motivation $\left(\mathrm{X}_{2}\right)$

b. Dependent variable: Job Satisfaction (Y)

Source: Data Analysis Results (2020) 
Table 9 Linearity Test: Job Motivation $\left(\mathrm{X}_{2}\right)$ on Job Satisfaction (Y)

ANOVA

\begin{tabular}{|c|c|c|c|c|c|c|c|}
\hline & & & Sum of Squares & df & Mean Square & $\mathrm{F}$ & Sig. \\
\hline \multirow[t]{5}{*}{$\mathrm{Y} * \mathrm{X}_{2}$} & \multirow{3}{*}{$\begin{array}{l}\text { Between } \\
\text { Groups }\end{array}$} & \multirow{3}{*}{$\begin{array}{l}\text { (Combined) } \\
\text { Linearity } \\
\text { Deviation from Linearity }\end{array}$} & 596.957 & 23 & 25.955 & 1.210 & .329 \\
\hline & & & 335.085 & 1 & 335.085 & 15.618 & .001 \\
\hline & & & 261.872 & 22 & 11.903 & .555 & .913 \\
\hline & \multirow{2}{*}{\multicolumn{2}{|c|}{$\begin{array}{l}\text { Within Groups } \\
\text { Total }\end{array}$}} & 472.000 & 22 & 21.455 & & \\
\hline & & & 1068.957 & 45 & & & \\
\hline
\end{tabular}

Source: Data Analysis Results (2020)

Table 10 Correlation Test: Job Motivation $\left(\mathrm{X}_{2}\right)$ and Job Satisfaction $(\mathrm{Y})$

Measures of Association

\begin{tabular}{|l|c|r|l|r|}
\hline & $\mathrm{R}$ & R-Squared & Eta & Eta Squared \\
\hline $\mathrm{Y} * \mathrm{X}_{2}$ & .560 & .313 & .747 & .558 \\
\hline
\end{tabular}

Source: Data Analysis Results (2020)

\subsection{Hypothesis 3: The Effect of Transactional Leadership Style and Job Motivation on Job Satisfaction}

The simultaneous effect of Transactional Leadership Style $\left(\mathrm{X}_{1}\right)$ and Job Motivation $\left(\mathrm{X}_{2}\right)$ on Job Satisfaction $(\mathrm{Y})$ is shown by the regression equation of: "Y $=21.925+0.814$ $\mathrm{X}_{1}+0.266 \mathrm{X}_{2}$ ", as displayed in Table 11 .

Table 12 shows that F-statistics (37.536) is greater than Ftable (3.21) with a significance level (0.000) less than 0.05 . Thus, it can be concluded that Transactional Leadership Style $\left(\mathrm{X}_{1}\right)$ and Job Motivation $\left(\mathrm{X}_{2}\right)$ have a significant effect on Job Satisfaction (Y) simultaneously.
Table 13 shows that the result of multiple-correlation test produces a number of 0.797 . This indicates that the relationship between Transactional Leadership Style $\left(X_{1}\right)$, Job Motivation $\left(\mathrm{X}_{2}\right)$, and Employees' Job Satisfaction (Y) is strong. The Adjusted Coefficient-of-Determination (Adjusted $\mathrm{R}^{2}$ ) of Transactional Leadership Style $\left(\mathrm{X}_{1}\right)$ and Job Motivation $\left(\mathrm{X}_{2}\right)$ toward Job Satisfaction $(\mathrm{Y})$ is 0.619 or $61.9 \%$. Therefore, this result illustrates that as much as $61.9 \%$ of the variation in Job Satisfaction variable is determined by the variations in Transactional Leadership Style and Job Motivation variables simultaneously, whereas the remaining $38.1 \%$ of the variation in Job Satisfaction variable is determined by other variables not examined in this study.

Table 11 Test of the Regression Equation: Transactional Leadership Style $\left(\mathrm{X}_{1}\right)$ and Job Motivation $\left(\mathrm{X}_{2}\right)$ on Job Satisfaction (Y)

Coefficients $^{\mathbf{a}}$

\begin{tabular}{|c|c|c|c|c|c|}
\hline \multirow[t]{2}{*}{ Model } & \multicolumn{2}{|c|}{ Unstandardized Coefficients } & \multirow{2}{*}{$\begin{array}{c}\text { Standardized Coefficients } \\
\text { Beta }\end{array}$} & \multirow[b]{2}{*}{ 㐖 } & \multirow[b]{2}{*}{ Sig. } \\
\hline & $\mathrm{B}$ & Std. Error & & & \\
\hline \begin{tabular}{|ll}
1 & (Constant)
\end{tabular} & 21.925 & 5.885 & & 3.726 & .001 \\
\hline $\begin{array}{l}\text { Transactional } \\
\text { Leadership Style }\left(\mathrm{X}_{1}\right)\end{array}$ & .814 & .132 & .60 & 6.169 & .000 \\
\hline Job Motivation $\left(\mathrm{X}_{2}\right)$ & .266 & .075 & .34 & 3.537 & .001 \\
\hline
\end{tabular}

a. Dependent variable: Job Satisfaction (Y)

Source: Data Analysis Results (2020)

Table 12 Significance Test: Transactional Leadership Style $\left(\mathrm{X}_{1}\right)$ and Job Motivation $\left(\mathrm{X}_{2}\right)$ on Job Satisfaction (Y)

ANOVA $^{b}$

\begin{tabular}{|ll|r|r|r|r|l|}
\hline \multicolumn{1}{|c|}{ Model } & Sum of Squares & \multicolumn{1}{c|}{ df } & Mean Square & F & Sig. \\
\hline 1 & Regression & 679.662 & 2 & 339.831 & 37.536 & $.000^{\mathrm{a}}$ \\
& Residual & 389.294 & 43 & 9.053 & & \\
Total & 1068.957 & 45 & & & \\
\hline
\end{tabular}

a. Predictors: (Constant), Transactional Leadership Style $\left(\mathrm{X}_{1}\right)$, Job Motivation $\left(\mathrm{X}_{2}\right)$ 
b. Dependent variable: Job Satisfaction (Y)

Source: Data Analysis Results (2020)

Table 13 Multiple Correlation Test: Transactional Leadership Style $\left(\mathrm{X}_{1}\right)$ and Job Motivation $\left(\mathrm{X}_{2}\right)$ on Job Satisfaction (Y)

Model Summary

\begin{tabular}{|c|r|r|r|r|}
\hline Model & \multicolumn{1}{|c|}{ R } & R-Squared & Adjusted R-Squared & Std. Error of Estimate \\
\hline 1 & $.797^{\mathrm{a}}$ & .636 & .619 & 3.009 \\
\hline
\end{tabular}

a. Predictors: (Constant), Transactional Leadership Style $\left(\mathrm{X}_{1}\right)$, Job Motivation $\left(\mathrm{X}_{2}\right)$

b. Dependent variable: Job Satisfaction (Y)

Source: Data Analysis Results (2020)

\section{DISCUSSIONS}

From the result of multiple-correlation test, the correlation coefficient (R) between Transactional Leadership Style $\left(\mathrm{X}_{1}\right)$, Job Motivation $\left(\mathrm{X}_{2}\right)$, and Employees' Job Satisfaction (Y) is strong, which is 0.797 .

The Adjusted Coefficient-of-Determination (Adjusted $\mathrm{R}^{2}$ ) of Transactional Leadership Style $\left(\mathrm{X}_{1}\right)$ and Job Motivation $\left(\mathrm{X}_{2}\right)$ toward Job Satisfaction $(\mathrm{Y})$ is 0.619 , which illustrates that $61.9 \%$ of variation in the Job Satisfaction variable is determined by the variation in Transactional Leadership Style $\left(\mathrm{X}_{1}\right)$ and Job Motivation $\left(\mathrm{X}_{2}\right)$ simultaneously, whereas the remaining $38.1 \%$ of variation in Job Satisfaction variable is determined by other variables not included in this study.

In regression analysis, the hypothesis tests had the significance values less than the specified significance level as referred in [9]. In this study, the level of significance set was $5 \%$. Based on the Tables above, it can be seen that all the hypotheses proposed in this study were accepted.

The result of the first hypothesis test indicates that transactional leadership style has a positive and significant effect on the employees' job satisfaction at PT. ABM Investama in South Jakarta, Indonesia. This result supports the formulation of hypothesis that was developed earlier in this study. Thus, the better the transactional leadership style applied by superiors, the higher the level of job satisfaction of PT. ABM Investama employees. This is in accordance with the theory developed by Bass (1990) in [10], which stated that leadership styles are able to change individual behavior. The same thing was also stated by [11] and [12], which stated that leadership style is important in an organization, because it has a major influence on employee behavior, attitudes, and job satisfaction.

The result of the second hypothesis test indicates that job motivation has a positive and significant effect on job satisfaction among the employees of PT. ABM Investama in South Jakarta, Indonesia. Job satisfaction is an individual matter. Thus, each individual will have a different level of satisfaction according to the value system that applies to him / her. Abraham Maslow in [13] explained that human beings have their own needs that arise depending on their individual interests. [2] also stated that to develop positive employee attitudes, leaders must continue to motivate their employees by considering their interests, skills, and needs so that the employees' job satisfaction is high.

The result of the third hypothesis test indicates that simultaneously transactional leadership style and job motivation positively and significantly affect job satisfaction among the employees of PT. ABM Investama in South Jakarta, Indonesia. This result is consistent and supports the opinion of Bass (1990) in [10] that transactional leaders motivate followers by exchanging rewards for work or tasks that have been carried out, for example, by giving awards for achievement, but on the contrary, punishing followers who have low performance. The same thing was also expressed by [14] that rewards and fulfillment of basic needs will affect the motivation of followers and in turn will affect job satisfaction.

\section{CONCLUSIONS}

Based on the results of hypothesis tests as described in Section 4, the conclusions can be presented as follows:

1. Transactional Leadership Style $\left(X_{1}\right)$ affects Job Satisfaction (Y). This is shown by a simple linearregression equation: $\mathrm{Y}=32.643+0.978 \mathrm{X}_{1}$ which is significant and linear. The relationship between Transactional Leadership Style $\left(\mathrm{X}_{1}\right)$ and Job Satisfaction (Y) is shown by the correlation coefficient $(\mathrm{R}=0.728)$, which is strong and significant. The contribution of Transactional Leadership Style $\left(\mathrm{X}_{1}\right)$ to Job Satisfaction (Y) is explained by the Coefficient-ofDetermination of $53 \%$. This means that $53 \%$ of the variation in Job Satisfaction variable (Y) can be explained by variation in Transactional Leadership Style $\left(\mathrm{X}_{1}\right)$, and the rest $(47 \%)$ is explained by other variables that are not in the scope of this study.

2. Job Motivation $\left(\mathrm{X}_{2}\right)$ affects Employees' Job Satisfaction $(\mathrm{Y})$. This is indicated by a simple linear-regression equation: $\mathrm{Y}=44.416+0.428 \mathrm{X}_{2}$ which is significant and linear. The relationship between Job Motivation $\left(\mathrm{X}_{2}\right)$ and Job Satisfaction (Y) is explained by the correlation coefficient $(\mathrm{R}=0.560)$, which is moderate and significant. The contribution of Job Motivation $\left(\mathrm{X}_{2}\right)$ to Job Satisfaction (Y) is shown by the Coefficient-ofDetermination of $31.3 \%$. This means that $31.3 \%$ of the variation in Job Satisfaction (Y) can be explained by the 
variation in Job Motivation $\left(\mathrm{X}_{2}\right)$, and the rest $(=68.7 \%)$ is explained by other variables that are not in the scope of this study.

3. Transactional Leadership Style $\left(\mathrm{X}_{1}\right)$ and Job Motivation $\left(\mathrm{X}_{2}\right)$ simultaneously affect Employees' Job Satisfaction (Y). This is indicated by the multiple linear-regression equation: $\mathrm{Y}=21.925+0.814 \mathrm{X}_{1}+0.266 \mathrm{X}_{2}$ which is significant. The relationship between Transactional Leadership Style $\left(\mathrm{X}_{1}\right)$, Job Motivation $\left(\mathrm{X}_{2}\right)$, and Job Satisfaction $(\mathrm{Y})$ is explained by the correlation coefficient $(\mathrm{R}=0.797)$, which is very strong and significant. The contribution of Transactional Leadership Style $\left(\mathrm{X}_{1}\right)$ and Job Motivation $\left(\mathrm{X}_{2}\right)$ to Job Satisfaction (Y) is shown by the Coefficient-ofDetermination of $61.9 \%$. This means that $61.9 \%$ of the variation in Job Satisfaction (Y) can be explained by the variations in Transactional Leadership Style $\left(\mathrm{X}_{1}\right)$ and Job Motivation $\left(\mathrm{X}_{2}\right)$, while and the rest $(38.1 \%)$ is explained by other variables that are not in the scope of this study.

Therefore, although job satisfaction has been created well, it can produce more optimum result when the factors that affect job satisfaction can be increased as well, such as transactional leadership style and job motivation.

Moreover, the transactional leadership style needs to be improved towards a better job satisfaction through the efforts including promising rewards for good performance, actively taking corrective actions by leaders when employees make mistakes, providing constructive criticism, and giving the opportunity to employees to be more responsible and make decisions on work when needed.

In addition, job motivation needs to be further improved by providing employees with the needs related to physiological needs in form of wages / salaries that are sufficient for their lives, giving awards to employees who excel, and holding activities outside the company environment so that employees and leaders can socialize well. By this way, the employees can be motivated to perform better.

\section{REFERENCES}

[1] Robbins, S. P., and Judge T. A. (2015). Organizational Behavior, $16^{\text {th }}$ Edition. Jakarta: Salemba Empat.

[2] Prabu, A. (2005). The Influence of Motivation on Employee Satisfaction of the National Family Planning Coordinating Board in Muara Enim Regency. Journal Management \& Business Sriwijaya, Volume 3, No. 6, pp. 1-25.

[3] Smith, P. C., Kendall, L., \& Hulin, C. L. (1969). The measurement of satisfaction in work and retirement: A strategy for the study of attitudes.

Chicago: Rand McNally.
[4] Wibowo. (2013). Perilaku dalam Organisasi, Edisi Pertama. Jakarta: Rajawali Pers.

[5] Marselius S. T. and Rita Andarika. (2004). Hubungan antara Persepsi Gaya Kepemimpinan Transformasional dan Transaksional dengan Kepuasan Kerja Karyawan. Jurnal PSYCHE, Vol. 1, No. 1, pp. 35-49.

[6] Priansa, D. J. (2016). Perencanaaan dan Pegembangan SDM. Bandung: Alfabeta.

[7] Mangkunegara, Anwar Prabu. (2015). Sumber Daya Manusia Perusahaan. Bandung: PT. Remaja Rosdakarya.

[8] Sugiyono. (2015). Metode Penelitian Manajemen. Bandung: Alfabeta.

[9] Imam Ghozali. (2016). Analisis Multivariate dengan Program IBM SPSS 23, Edisi ke-8. Semarang: Badan Penerbit Universitas Diponegoro.

[10] Steers, R.M. Porter W, and Bigley, G.A. (Eds).1996. Motivation and Leadership at Work, Sixth Edition, New York: The McGraw-Hill Companies.

[11] Voon, Mung Ling., Lo, May Chiun., Kwang Sing, Ngui., Ayob, N. B. (2011). The Influence of Leadership Styles on Employees' Job Satisfaction in Public-Sector Organizations in Malaysia. International Journal of Business, Management, and Social Sciences, Vol. 2, No. 1, pp. 24-32.

[12] Rusdiyanto, Wahyu., dan Riani, Asri Laksmi. (2015). Pengaruh Kepemimpinan Transformasional dan Transaksional pada Organizational Citizenship Behaviour dengan Kepuasan Kerja sebagai Pemediasi. Jurnal Economia, Vol. 11, No. 2, pp. 161-168.

[13] Sutrisno, Edy. (2009). Manajemen Sumber Daya Manusia, Edisi Pertama. Jakarta: Kencana Prenada Media Group.

[14] J. Wagimo and Ancok D. The Relationship between Transformational and Transactional Leadership and Motivation of Subordinates in the Military. Journal of Psychology, Volume 32, No. 2, 112-127. 